Arch. Histol. Cytol., Vol. 62, No. 5 (1999)

p. $413-422$

\title{
The Role of Kupffer Cells in Liver Regeneration*
}

\author{
Toshiyuki TaKeishi ${ }^{1,2}$, Kenichiro Hirano ${ }^{1,2}$, Takashi Kobayashi ${ }^{1,2}$, Go Hasegawa ${ }^{1}$, \\ Katsuyoshi HatakeYaMA ${ }^{2}$ and Makoto NaIto ${ }^{1}$ \\ Second Department of Pathology ${ }^{1}$, and First Department of Surgery², Niigata University School of Medicine, Niigata, Japan
}

Received November 9, 1999

\begin{abstract}
Summary. The liver has a remarkable proliferative capacity after a partial hepatectomy. Previous studies have indicated that Kupffer cells have the potential to exert both stimulatory and inhibitory influences on hepatocyte proliferation. To elucidate the role of Kupffer cells in liver regeneration, mice were selectively depleted of Kupffer cells by injection of liposome-encapsulated dichloromethylene diphosphonate (lipo-MDP) at day 3 after a two-thirds hepatectomy. Results showed that liver regeneration was delayed after Kupffer cell-depletion. In control mice, hepatocyte growth factor (HGF) mRNA expressions were enhanced during liver regeneration and expressions of HGF were localized in fat-storing cells (Ito cells). In Kupffer celldepleted mice, the number of HGF-expressing cells decreased in the regenerating liver, and expressions of $\mathrm{HGF}$ and its receptor ( $c$-met) as well as other growth factors/cytokines were less prominent than in control mice. In contrast, expressions of TNF- $\alpha$, another potent cytokine involved in liver regeneration, did not differ between Kupffer cell-depleted and control mice during the regeneration. Administration of TNF- $\alpha$ antibody did not reduce the expression of HGF or liver regeneration. These findings imply that Kupffer cells play a stimulatory role in liver regeneration by enhancing HGF expression via TNF- $\alpha$-non-mediated mechanisms.
\end{abstract}

Liver regeneration is a fundamental and orchestrated response to a loss of hepatic tissue (Michalopoulos and DEFRANCES, 1997). In the partial hepatectomy model (HIGGins and ANDERSON, 1931) in which twothirds of the liver of a rat is removed, the residual liver lobes enlarge to compensate for the removed mass of the liver within 7-10 days. This response is induced by specific external stimuli and involves sequential changes in gene expression, growth factor production, and morphological structure. Liver regeneration commences soon after a partial hepatectomy.
Hepatocyte DNA synthesis peaks at $24 \mathrm{~h}$, whereas other cell types proliferate later (OGAWA et al., 1979). Several growth factors, including hepatocyte growth factor (HGF) (GHERARDI and STOKER, 1990; GAK et al., 1992; MAHER, 1993; SHIOTA et al., 1994; UEHARA et al., 1995; SCHMIDT et al., 1995; MATSUDA et al., 1997; MATSUMOTO and NAKAMURA, 1997), epidermal growth factor (EGF) (SKov OLSEN et al., 1988; NOGU. CHI et al., 1991), transforming growth factor $-\beta$ (TGF$\beta$ ) (CARR et al., 1986), interleukin-6 (IL-6) (CRESSMAN et al., 1996), and tumor necrosis factor- $\alpha$ (TNF- $\alpha$ ) (CORNELl et al., 1990; DiEHL et al., 1994; YAMAdA et al., 1997), seem to play important roles in this process. Because Kupffer cells are known to produce most of these growth factors and cytokines, Kupffer cells are postulated to play a key role in liver regeneration.

Macrophage depletion has proved a useful tool for elucidating the macrophage function and kinetics. Since liposome-encapsulated dichloromethylene diphosphonate (lipo-MDP) induces macrophage apoptosis (NAITO et al., 1986), tissue macrophages can be depleted by selecting a suitable administration route (VAN ROOIJEN and NIEUWNMEGEN, 1984; VAN ROOIJEN et al., 1989a, b; DELEMARRE et al., 1990; VAN ROOIJEN and SANDERS, 1994). Using this method, we investigated macrophage repopulation (YAMAMOTO et al., 1996) and macrophage function in the host defense against Listeria (EBE et al., 1999). However, there has been only one study testing this method to clarify the role of Kupffer cells in liver regeneration (BOULTon et al., 1998).

In this study, we performed a partial hepatectomy in mice and then depleted the animals of Kupffer cells by an intravenous injection of lipo-MDP in order to clarify the role of Kupffer cells in liver regeneration. The roles of HGF and TNF- $\alpha$ were also investigated by examining the expression of their mRNAs by

\footnotetext{
*This study was supported in part by Grants-in-Aid for Scientific Research from the Ministry of Education, Science, and Culture of Japan.
} 
reverse transcriptase polymerase chain reaction (R'TPCR) and immunohistochemistry.

\section{MATERIALS AND METHODS}

\section{Preparation of liposome-entrapped $M D P$}

Multilamellar liposomes were prepared as described (Yамамото et al., 1996, EBE et al., 1999). In brief, $58.72 \mathrm{mg}$ phosphatidylcholine (Nihon Seika Inc, Hyogo, Japan), $8.75 \mathrm{mg}$ dehexadecyl phosphate, and $24.75 \mathrm{mg}$ cholesterol (Wako, Tokyo, Japan) were dissolved in chloroform in a round-bottom flask and dried under reduced pressure. The lipids were then hydrated in 5 $\mathrm{ml}$ of phosphate buffered saline containing $650 \mathrm{mM}$ $(0.9455 \mathrm{~g}) \mathrm{MDP}$ and vortex-mixed at room temperature. The liposomes were extruded through polycarbonate membranes (Costar Corporation, Pleasanton, CA) with a pore size of $0.8 \mu \mathrm{m}$. Non-encapsulated MDP was removed by ultracentrifugation. The liposomes were composed of phosphatidyl choline/ dehexadecyl phosphate/cholesterol at a molar ratio of $5: 1: 4$.

\section{Animals}

$\mathrm{BALB} / \mathrm{c}$ mice were purchased from Charles River Inc. Japan (Tokyo) and maintained under routine conditions at the Laboratory Animal Center of Niigata University School of Medicine. Eight-weekold male mice were used. The partial hepatectomy consisted of the surgical removal of two-thirds of the liver, leaving only the right lateral and caudate lobes. The operation was performed under ether anesthesia and aseptic conditions. Before suturing, sulfanilamide powder was administered intraperitoneally. Mice were divided into two groups. The mice in one group were sacrificed and their livers removed at various intervals after partial hepatectomy. In the other group, mice were intravenously injected with $0.5 \mathrm{ml}$ of lipo-MDP at 3 days after partial hepatectomy and the livers removed at various intervals. Three other mice were killed by ether anesthesia at various times.

\section{Monoclonal antibodies}

The rat monoclonal antibodies, F4/80, BM8, and ER-MP58 (BMA Biomedicals, Augst, Switzerland), were used at a dilution of $1: 100 . F 4 / 80$ and BM8 recognize antigens on murine macrophages, and ER-MP58 recognizes macrophage precursors at different stages of differentiation (LEENEN et al., 1990, 1994). Rabbit anti-TNF- $\alpha$ antiserum and antiHGF antiserum were kindly provided by Dr. N. MuKaidA, Kanazawa Cancer Institute, and Prof. T.
NAKAMURA, Osaka University, and were used at a dilution of $1: 100$ and $1: 500$, respectively.

\section{Immunohistochemistry}

The liver was fixed for $4 \mathrm{~h}$ at $4^{\circ} \mathrm{C}$ in periodate-lysineparaformaldehyde, washed for $4 \mathrm{~h}$ with phosphate buffered saline containing 10,15 , or $20 \%$ sucrose, embedded in OCT compound (Miles, Elkhart, IN), frozen in dry ice-acetone, and cut by cryostat (Bright, Huntington, UK) into $6 \mu$-thick sections. After the inhibition of endogenous peroxidase activity by the method by IsOBE et al. (1977), immunohistochemistry was performed using the anti-mouse monoclonal antibodies described above. Anti-rat immunoglobulinhorseradish peroxidase-linked $\mathrm{F}(\mathrm{ab})_{2}$ fragment (Amersham, Poole, UK) was used as a secondary antibody and sheep anti-rabbit Ig-horseradish peroxidase-linked $\mathrm{F}(\mathrm{ab})_{2}$ fragment (Amersham) was used as a secondary antibody for rabbit polyclonal antibodies. After visualization with 3,3'-diaminobenzidine (DAB; Dojin Chemical, Co., Kumamoto, Japan) and nuclear staining with methylene green, the sections were mounted with resin. After visualization with 3,3'-diaminobenzidine (Dojin Chemical Co.), nuclear staining with methylene green and mounting with resin, the positive cells with nuclei per $1 \mathrm{~mm}^{2}$ were counted using a light microscope.

Immunohistochemical double staining with $\mathrm{F} 4 / 80$ and the anti-HGF antibody was performed as described (YAMAMOTO et al., 1996) with a minor modification. In brief, following inhibition of the endogenous peroxidase activity, cryostat sections were incubated with $\mathrm{F} 4 / 80$. After incubation with anti-rat Ig-horseradish peroxidase-linked $\mathrm{F}(\mathrm{ab})_{2}$ fragment, the reaction was stained brown with 3,3'-diaminobenzidine. The sections were then incubated with the anti-HGF antiserum. After incubation with sheep anti-rabbit Ig-horseradish peroxidase-linked $\mathrm{F}(\mathrm{ab})_{2}$ fragment (Amersham), they were incubated with Nickel chloride solution in 3,3'-diaminobenzidine substrate kit (Vector Lab, Burlingame, CA) and processed as above to stain positive cells blue-black.

\section{Autoradiography with $\left[{ }^{3} \mathrm{H}\right]$ thymidine}

$\left[{ }^{3} \mathrm{H}\right]$ thymidine (specific activity, $3.0 \mathrm{TBq} / \mathrm{mmole}$ ) was obtained from Du Pont (Wilmington, DE). Mice were intravenously injected with $1 \mathrm{MBq}$ of $\left[{ }^{3} \mathrm{H}\right]$ thymidine for $60 \mathrm{~min}$ before sacrifice. After immunohistochemical staining with ER-MP 58, BM 8, and F4/80, slides were dipped into a Sakura NR-M2 liquid emulsion (Konica, Tokyo, Japan) diluted 1:2 with water, exposed for two weeks at $4{ }^{\circ} \mathrm{C}$, and developed. Cells with ten or more grains over the nucleus above the background were considered as labeled. 
$R N A$ isolation and $m R N A$ analysis by reverse transcriptase polymerase chain reaction ( $R T-P C R$ )

Total cellular RNA was isolated from the liver of control and lipo-MDP-treated mice at 1, 2, 3, 5, 7, 10, and 14 days after a partial hepatectomy by phenolchloroform extraction as described previously (YAMAMOTO et al., 1996). PCR amplification was performed using a TP cycler-100 (Toyobo, Osaka, Japan). All the PCR primers were made to order by Kurabo Biomedicals (Osaka, Japan). The oligonucleotides used are listed in Table 1 . The samples were separated on a $1.5 \%$ low melting agarose gel containing $0.3 \mu \mathrm{g} /$ $\mathrm{ml}$ of ethidium bromide, and bands were visualized and photographed using ultraviolet transillumination.

\section{RESULTS}

\section{Liver regeneration in Kupffer cell-depleted and non-depleted mice}

In normal mice, F4/80- and BM8-positive Kupffer cells were stellate or spindle in shape and found predominantly in the peripheral zone of the hepatic lobules. After the partial hepatectomy, the weight of the remaining liver increased and the original liver weight was restored at 7 days accompanying an overshoot thereafter (Fig. 1). In mice administered with lipo-MDP at 3 days following the partial hepatectomy, the recovery of the liver weight was delayed for 7 days, but reached the control level at 14 days.

Table 1. Oligonucleotides used.

\begin{tabular}{|c|c|c|c|}
\hline mRNA & & Primers & Sequences $\left(5^{\prime}\right.$ to $\left.3^{\prime}\right)$ \\
\hline $\mathrm{HGF}$ & $\begin{array}{l}\text { Sense } \\
\text { Antisense }\end{array}$ & $370 \mathrm{bp}$ & $\begin{array}{l}\text { CTGGGGCTACACTGGATTG } \\
\text { GATGCTTCAAACACACTGGC }\end{array}$ \\
\hline c-met & $\begin{array}{l}\text { Sense } \\
\text { Antisense }\end{array}$ & $688 \mathrm{bp}$ & $\begin{array}{l}\text { TCACTCTTGGGAATCTGCCTGA } \\
\text { GCAACAGAGAAGGATATGGAGC }\end{array}$ \\
\hline EGF & $\begin{array}{l}\text { Sense } \\
\text { Antisense }\end{array}$ & $334 \mathrm{bp}$ & $\begin{array}{l}\text { CATTGATGGCCCACACTG } \\
\text { TGAGAGGTTCCACGCGCA }\end{array}$ \\
\hline TNF- $\alpha$ & $\begin{array}{l}\text { Sense } \\
\text { Antisense }\end{array}$ & $309 \mathrm{bp}$ & $\begin{array}{l}\text { GGCAGGTCTACTTTGGAGTCATTGC } \\
\text { ACATTCGAGGCTCCAGTGAATTCGG }\end{array}$ \\
\hline TGF- $\beta$ & $\begin{array}{l}\text { Sense } \\
\text { Antisense }\end{array}$ & $326 \mathrm{bp}$ & $\begin{array}{l}\text { GCCCTGGATACCAACTATTG } \\
\text { CAGGAGCGCACAATCATGTT }\end{array}$ \\
\hline IL-6 & $\begin{array}{l}\text { Sense } \\
\text { Antisense }\end{array}$ & $130 \mathrm{bp}$ & $\begin{array}{l}\text { TGGAGTCACAGAAGGAGTGGCTAAG } \\
\text { TCTGACCACAGTGAGGAATGTCCAC }\end{array}$ \\
\hline
\end{tabular}

\section{Administration of neutralizing anti-TNF- $\alpha$ antibody}

Antiserum obtained from rabbits immunized with mouse TNF- $\alpha$ expressed in Escherichia coli was generously provided by Dr. MukAidd, Kanazawa University. Mice were injected i.v. with $200 \mu \mathrm{g}$ of IgG fractions of rabbit anti-mouse TNF- $\alpha$ at 3 days after partial hepatectomy, then sacrificed at various intervals and their livers removed. The liver weight was measured, and RNA was extracted as described above. Three other mice were killed by ether anesthesia at various times.

\section{Statistics}

The significance of the data was evaluated by ANOVA by repeated measures.

\section{Changes in the number of Kupffer cells and macrophage precursors in the liver of Kupffer cell-depleted and non-depleted mice after partial hepatectomy}

In the control mouse liver, abundant Kupffer cells were mainly distributed in the peripheral zone of the hepatic lobules. There were a few ER-MP58-positive cells in the control mouse liver. The number of Kupffer cells decreased slightly at $12 \mathrm{~h}$, but thereafter increased gradually till day 10 after the partial hepatectomy (Fig. 2a). Mitotic figures of Kupffer cells were often observed. The number of ER-MP58-positive cells in the control mice increased up to three fold at 7 days (Fig. $2 b$ ).

At 1 and 2 days after the administration of lipoMDP to partially hepatectomized mice, Kupffer cells were almost completely depleted in the liver. The number of Kupffer cells gradually recovered, with a 


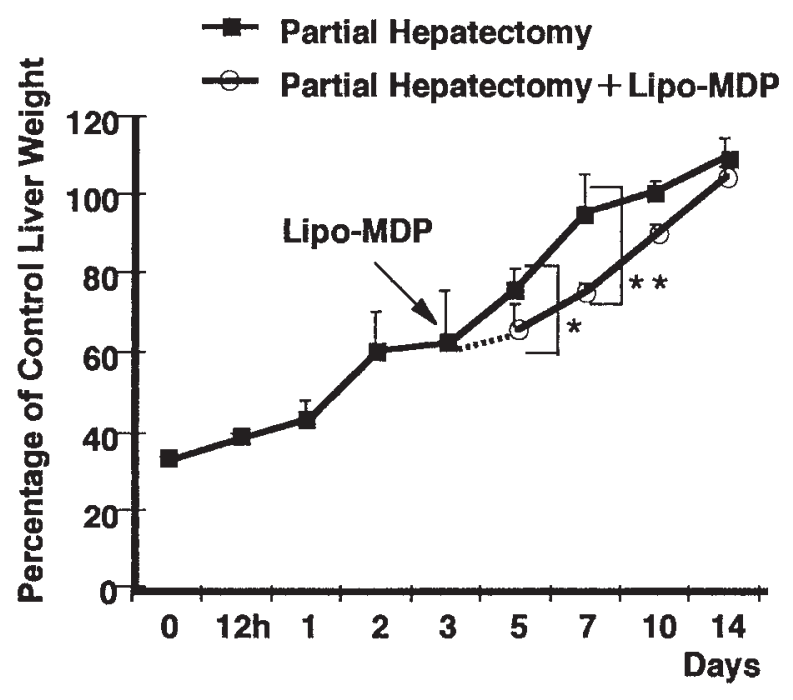

Fig. 1. The liver weight of control and Kupffer celldepleted mice following a partial hepatectomy. ${ }^{*} \mathrm{P}<0.05$, ${ }^{* *} \mathrm{P}<0.01$.

return to normal levels at 7 days after lipo-MDP administration (Fig. 2a). The number of ER-MP58positive cells increased slightly in partially hepatectomized Kupffer cell-depleted mice (Fig. 2b).

\section{Proliferative potential of Kupffer cells in the liver of Kupffer cell-depleted and non-depleted mice after partial hepatectomy}

To examine the proliferative potential of Kupffer cells, macrophage precursors, and hepatocytes, $\left[{ }^{3} \mathrm{H}\right]$ thymidine was given to Kupffer cell-depleted and non-depleted mice at various times after the partial hepatectomy followed by processing by combined immunohistochemistry and autoradiography. In the control mice, the percentage of $\left[{ }^{3} \mathrm{H}\right]$-thymidinelabeled F4/80-positive cells increased up to 6.5 -fold at
5 days. The labeling rate of ER-MP58-positive cells also increased during the process of liver regeneration. In Kupffer cell-depleted mice, the $\left[{ }^{3} \mathrm{H}\right]$-thymidinelabeled ER-MP58- and F4/80-positive cells were markedly decreased at 5 days, but increased thereafter (Fig. 3). Hepatocytes showed a marked proliferative capacity after partial hepatectomy. However, Kupffer cell-depletion resulted in a reduction in the rate of proliferation of hepatocytes (Table 2).

Effects of Kupffer cell-depletion on cytokine/ growth factor mRNA expressions in the liver

IL- 6 and TGF- $\beta$ mRNAs were detected in the liver of untreated normal mice. Expressions of TNF- $\alpha$, TGF$\beta$, M-CSF, and EGF were enhanced soon after partial hepatectomy. HGF mRNA expression was not detected in the liver of normal mice, but was increased after partial hepatectomy followed by a diminution at 14 days. C-met mRNA expression was also upregulated from day 1 to day 7 .

Cytokine mRNA expression was suppressed in the liver of Kupffer cell-depleted mice. However, HGF, c-met, and TNF- $\alpha$ mRNA expression was prolonged in Kupffer cell-depleted mice as compared with nondepleted mice (Fig. 4).

Immunohistochemically, HGF-expressing cells were hardly detected in the hepatic sinusoids of normal mice. Three days after the partial hepatectomy, several spindle- or stellate-shaped cells in the sinusoid showed an unequivocal positive reaction to an anti-HGF antibody (Fig. 5a). Immunohistochemical double staining demonstrated that HGFexpressing cells were Ito cells, not Kupffer cells (Fig. $5 b)$. The number of HGF-expressing cells decreased after 7 days (Fig. 6). In Kupffer cell-depleted mice, however, HGF-expressing cells were less numerous during liver regeneration. HGF mRNA expressions were less prominent in the regenerating liver of Kupffer cell-depleted mice than in that of nondepleted mice (Fig. 6).

Table 2. ${ }^{3} \mathrm{H}$-thymidine labeling rate of liver cells in Kupffer cell-depleted and non-depleted control mice after partial hepatectomy.

\begin{tabular}{|c|c|c|c|c|c|c|}
\hline & 0 & 2 & 3 & 5 & 7 & 10 days \\
\hline Control mice & $3 \pm 2$ & $12 \pm 5$ & $13 \pm 4$ & $18 \pm 67 *$ & $11 \pm 3$ & $4 \pm 2 \%$ \\
\hline Kupffer cell-depleted mice & & & & $6 \pm 3$ & $8 \pm 3$ & $6 \pm 2 \%$ \\
\hline
\end{tabular}

Kupffer cells were depleted at 3 days after partial hepatectomy. ${ }^{* *} \mathrm{P}<0.01$ 

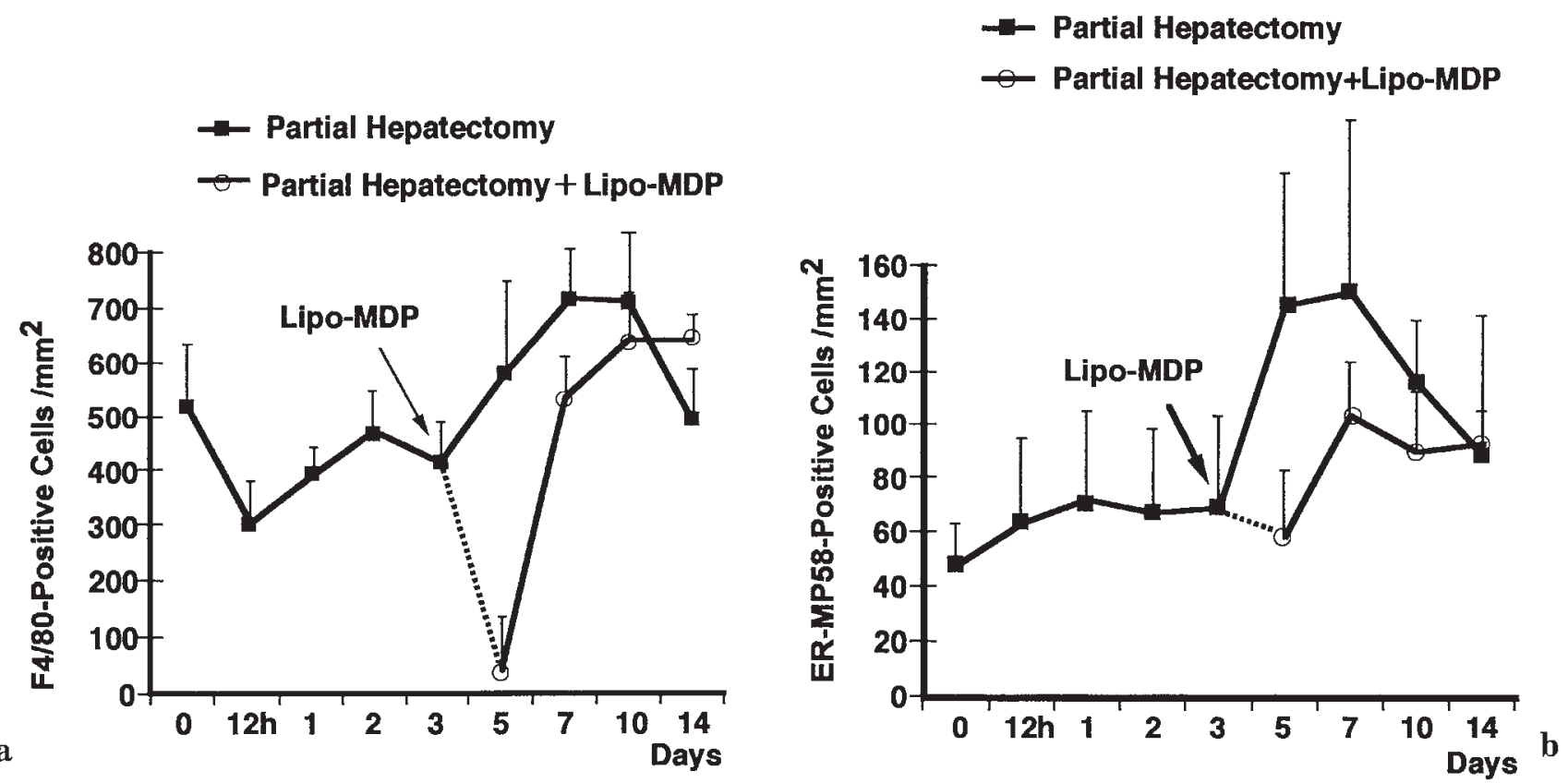

Fig. 2. Changes in the number of F4/80-positive Kupffer cells (a) and ER-MP58-positive macrophage precursors (b) in the livers of Kupffer cell-depleted and non-depleted mice after a partial hepatectomy.
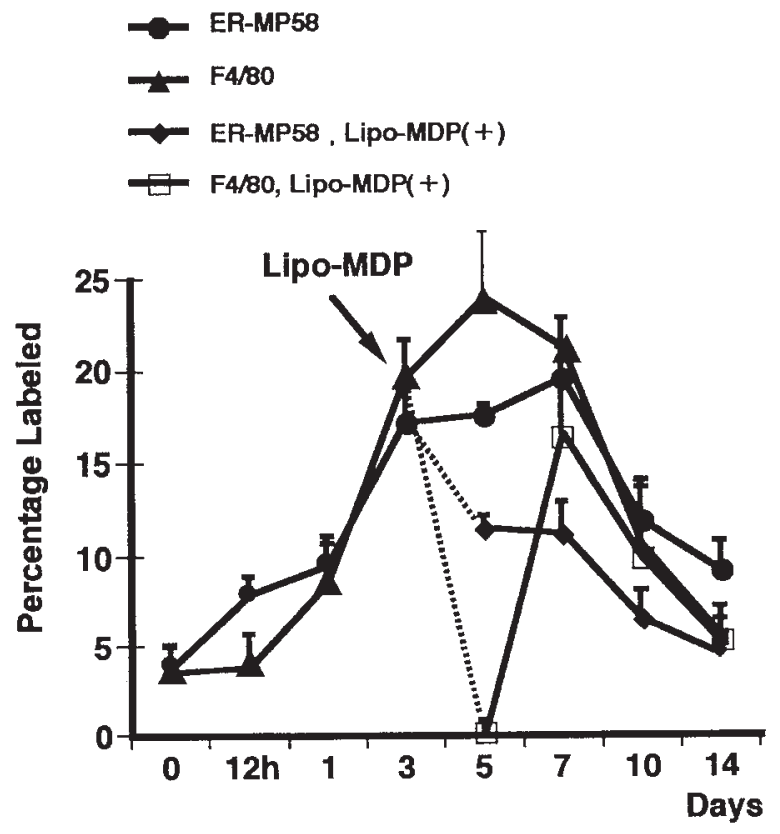

Fig. 3. Proliferative potential of Kupffer cells and macrophage precursors in the livers of Kupffer celldepleted and non-depleted mice after a partial hepatectomy. $\left[{ }^{3} \mathrm{H}\right]$-thymidine autoradiography.

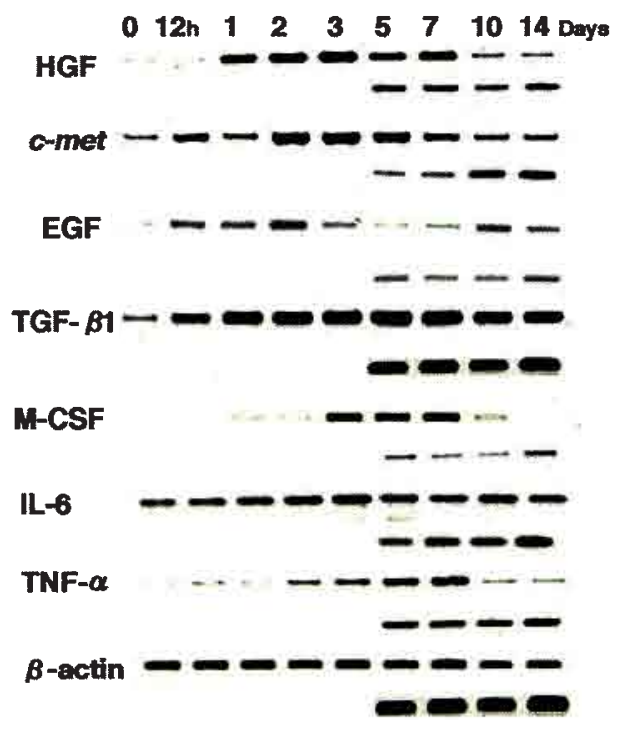

Fig. 4. Expression of cytokine mRNAs in the livers of Kupffer cell-depleted and non-depleted mice after partial hepatectomy. Upper lane: partial hepatectomy. Lower lane: partial hepatectomy + lipo-MDP. RT-PCR. 

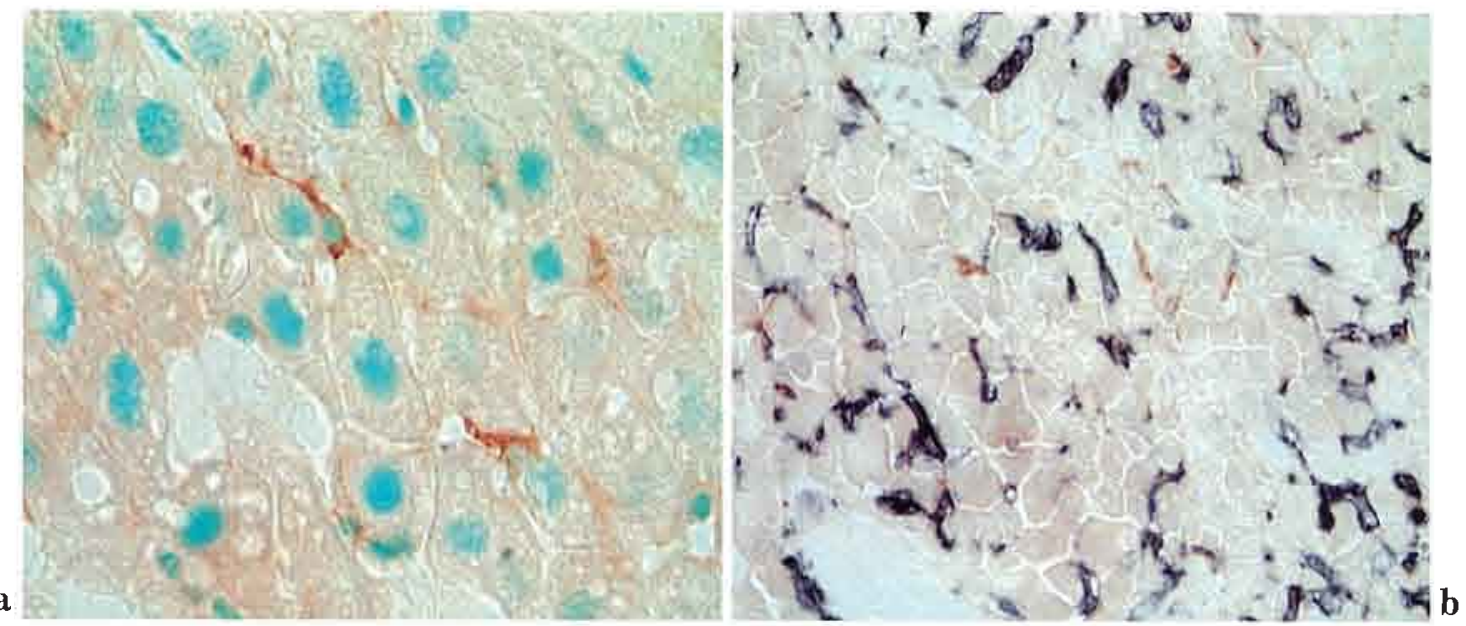

Fig. 5. HGF-expressing cells at three days after a partial hepatectomy. a. HGF-expressing cells are stellate in shape. Immunohistochemical staining using an anti-HGF antibody. $\times 800$. b. Kupffer cells are stained blue-black and HGF-expressing cells, brown. There are no double-positive cells. Immunohistochemical double staining using F4/80 and an anti-HGF antibody. $\times 200$

\section{- Partial Hepatectomy - Partial Hepatectomy+ Lipo-MDP}

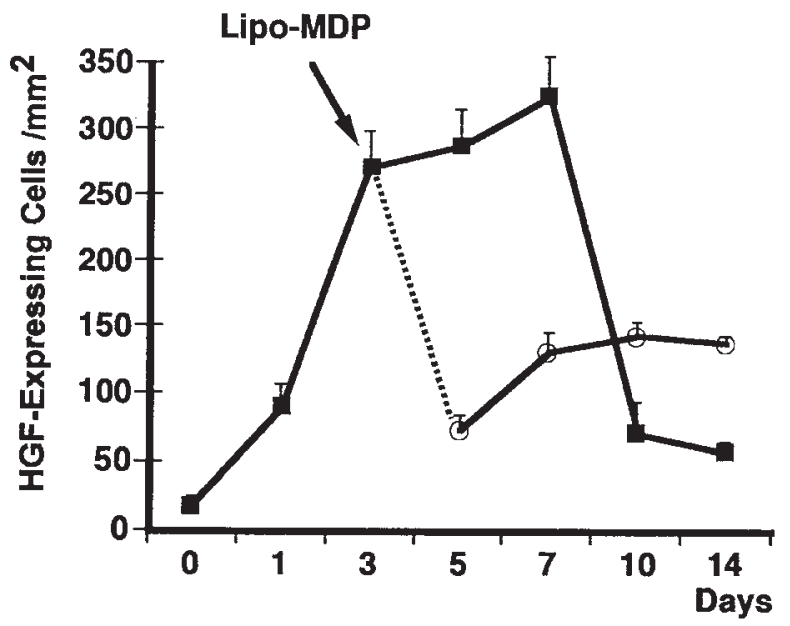

Fig. 6. The number of HGF-expressing cells in the livers of Kupffer cell-depleted and non-depleted mice after partial hepatectomy.
Effects of an anti-mouse TNF- $\alpha$ antibody on liver regeneration

Administration of anti-mouse TNF- $\alpha$ antibody did not abrogate the increase in the liver weight of hepatectomized mice (Fig. 7). HGF mRNA expressions in the regenerating liver did not significantly differ between TNF- $\alpha$ antibody-treated and nontreated mice (Fig. 8).

\section{DISCUSSION}

The present study provides in vivo evidence that Kupffer cells modulate hepatocyte proliferation. Previous studies have indirectly indicated that Kupffer cell products control liver regeneration positively or supressively. Conflicting views have been presented on whether Kupffer cells exert stimulatory or suppressive effects on hepatocyte proliferation. In this study we applied a selective Kupffer cell depletion method to examine the overall contribution of Kupffer cells to liver regeneration.

Various models have been employed to clarify the functional role of Kupffer cells. However, many agents such as silicates, asbestos, and carageenan (KAGAN and HARTMANN, 1984) are inappropriate for this purpose, as they activate macrophages to secrete biologically active substances. Two methods have been developed to deplete macrophages selectively: the administration of gadolinium chloride and use of lipo-MDP. Gadolinium chloride enhances hepatocyte 


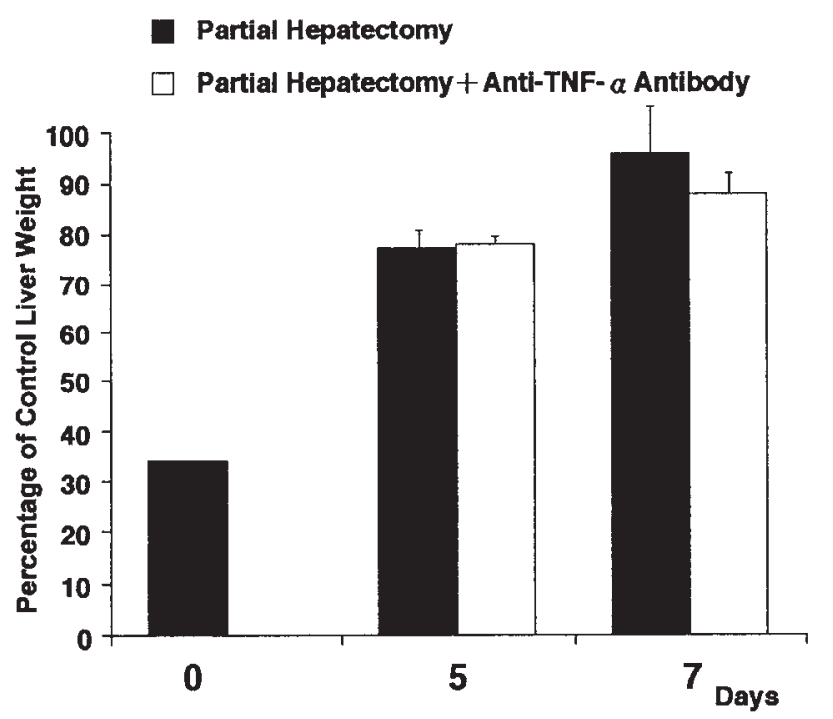

Fig. 7. Influence of anti-mouse TNF- $\alpha$ antibody on liver regeneration.

proliferation not only in the regenerating liver but also in the non-regenerating liver (HARDONK and DiJKhuis, 1993). Hepatocyte proliferation in gadolinium chloride-treated partially hepatectomized rats is attributed to the production of TNF- $\alpha$ (RAI et al., 1996), and that in gadolinium chloride-treated nonhepatectomized rats to the production of HGF by Ito cells (SCHIRMACHER et al., 1992). However, the use of gadolinium chloride to delete Kupffer cells raises difficulties in interpretation. There is controversy as to whether gadolinium chloride eliminates macrophages or alters macrophage function (LAZAR, 1979; HARDONK et al., 1995). We have immunohistochemically observed that gadolinium chloride changes the phenotype of Kupffer cells in rats, but does not deplete them. Furthermore, gadolinium chloride is toxic and retained in hepatocytes. In contrast, we demonstrated that lipo-MDP induces macrophage apoptosis and selectively depletes macrophages (NAITO et al., 1996). In our experiment Kupffer cells were shown to be eliminated for three days, as evidenced by the absence of F4/80- and BM8-positive cells. Therefore, lipo-MDP appears to be more suitable tool for investigating the effect of Kupffer cells on liver regeneration.

This study suggested that Kupffer cells form a microenvironment for hepatocyte proliferation by regulating the production of $\mathrm{HGF}$. $\mathrm{HGF}$ is a heterodimeric glycoprotein consisting to both a heavy and a light chain of approximate molecular weights of
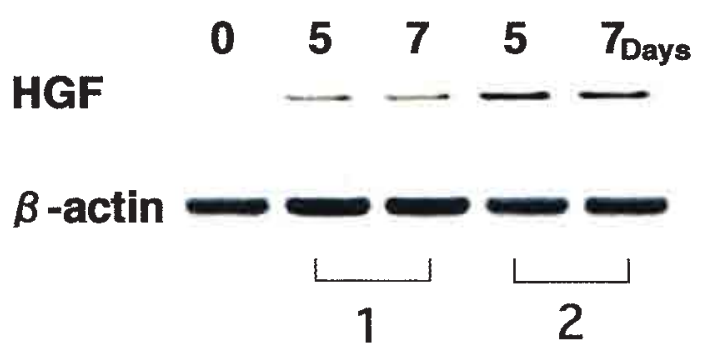

Fig. 8. HGF mRNA expressions in the regenerating livers of anti-TNF- $\alpha$ antibody-treated (1) and non-treated mice (2).

64,000 and 32,000, respectively (GHERARDI and STOKER, 1990; GAK et al., 1992; SHIOTA et al., 1994; SCHMidT et al., 1995; MATSUDA et al., 1997; MATSU. MOTO and NAKAMURA, 1997). HGF is the most potent mitogen for hepatocytes. It is not produced by hepatocytes, but is secreted by mesenchymal cells in the body. In the liver, HGF has been known to be synthesized by Kupffer cells, Ito cells, and endothelial cells (MAHER, 1993). It was reported that the amount of HGF mRNA produced by nonparenchymal cells increases and reaches a maximum 18-24 h after a partial hepatectomy (GAK et al., 1992). The present study also demonstrated that HGF mRNA expression was upregulated after the partial hepatectomy. Although an extrahepatic source of HGF may induce hepatocyte proliferation, intrahepatically produced HGF is of prime importance for hepatocyte replication. With Kupffer cell depletion, the expression of HGF mRNA was reduced and prolonged after partial hepatectomy. Rates of weight gain and $\left[{ }^{3} \mathrm{H}\right]$-thymidine labeling of hepatocytes in Kupffer cell-depleted mice were about $25 \%$ of those in non-depleted mice. Decreased HGF production may be largely responsible for such a reduction and retardation of liver regeneration.

As indicated above, HGF has been suggested to be produced both by Ito cells and Kupffer cells (MAHER, 1993). We immunohistochemically observed HGF expression in Ito cells after the partial hepatectomy. We also found that much less HGF was expressed in 
Ito cells in Kupffer cell-depleted mice than in control mice during liver regeneration. These findings indicate that Ito cells are a major source of HGF in the liver, and that Kupffer cells may control HGF production in Ito cells. In contrast to the result of the present study, BoulTon et al. (1998) demonstrated by the same method that liver regeneration was enhanced following Kupffer cell depletion. However, they also observed a reduced expression of HGF mRNA in Kupffer cell-depleted animals. They assumed that the enhanced proliferation of hepatocytes after Kupffer cell depletion was associated with an alteration in the balance of growth factors in the liver. The reaction of hepatocytes to Kupffer cell depletion may be related to the protocol for Kupffer cell depletion.

Besides HGF, TNF- $\alpha$ is considered to be an important component of the early signaling pathways leading to liver regeneration (CORNELL et al., 1990). Endotoxin promotes TNF- $\alpha$ production by Kupffer cells, and an anti-TNF- $\alpha$ antibody reduces liver regeneration (DIEHL et al., 1994). Liver regeneration of TNF- $\alpha$ receptor knockout mice has been reported to be reduced (YAMADA et al., 1997). In the present study, TNF- $\alpha$ expressions were similar between the control and Kupffer cell-depleted mice during liver regeneration. We then injected an anti-TNF- $\alpha$ antibody into mice at three days after partial hepatectomy, but no retardation of liver regeneration or reduction of HGF production was observed. These findings suggest that TNF- $\alpha$ does not contribute to liver regeneration at 3 days after partial hepatectomy. Presumably, TNF- $\alpha$ may play an important role in hepatocyte proliferation immediately after partial hepatectomy.

Various cell types proliferate during liver regeneration. Kupffer cell proliferation is prominent during liver regeneration (WIDMANN and FAHIMI, 1975; BOUWENS and WISSE, 1985), as has been observed after the administration of macrophage stimulants (DEIMANN and FAHIMI, 1979; BOUWENS and WISSE, 1985; YAMADA et al., 1990; NAITO and TAKAHASHI, 1991). The present study revealed a high proliferative capacity for Kupffer cells during liver regeneration, suggesting that the self-replication of Kupffer cells is largely responsible for their increased numbers in liver regeneration. The density of Kupffer cells decreases in the early stage of liver regeneration because of the rapid proliferation of hepatocytes. After this stage, an influx of macrophage precursors is considered to be involved in the expansion of macrophage populations in the regenerating liver (BOUWENs et al., 1984). YAMAMOTo et al. (1996) demonstrated that ER-MP58-positive macrophage precursors proliferated after Kupffer cell depletion. In the present study, we also observed that ER-MP58- positive cells proliferated and increased in number during liver regeneration. Besides Kupffer cell proliferation, the rapid proliferation and differentiation of intrahepatic macrophage precursors appears to be involved in the increases of Kupffer cells in liver regeneration. Enhanced M-CSF expression may be one of the factors involved in macrophage differentiation and proliferation as reported previously (YAMAMOTO et al., 1996).

In summary, HGF as well as several cytokines are involved in liver regeneration. Kupffer cells play an important role in liver regeneration by modulating the production of these molecules.

Acknowledgments. We extend our appreciation to Prof. K. TaKaHASHI, Kumamoto University School of Medicine, for advice and critical review. We thank Prof. T. NAKAMURA for providing an anti-murine HGF antibody. We also thank Mr. K. SATO and S. MOMOZAKI for excellent technical assistance. We are grateful to Kissei Pharmaceutical Co. for supplying dichloromethylene diphosphonate, and Nippon Fine Chemical Co. for providing phosphatidylcholine.

\section{REFERENCES}

Boulton, R. A., M. R. Alison, M. Golding, C. Selden and H. J. HoDGson: Augmentation of the early phase of liver regeneration after $70 \%$ partial hepatectomy in rats following selective Kupffer cell depletion. J. Hepatol. 29: 271-280 (1998).

Bouwens, L. and E. Wisse: Proliferation, kinetics, and fate of monocytes in rat liver during a zymosan-induced inflammation. J. Leukoc. Biol. 37: 531-543 (1985).

Bouwens, L., M. Baekeland and E. WISSE: Importance of local proliferation in the expanding Kupffer cell poptlation of rat liver after zymosan stimulation and partial hepatectomy. Hepatology 4: 213-219 (1984).

Carr, B. I., I. Hayashi, E. L. Braum and H. L. Moses: Inhibition of DNA synthesis in rat hepatocytes by platelet-derived type $\beta$ transforming growth factor. Cancer Res. 46: 2330-2334 (1986).

Cornell, R. P., B. L. LILJEquist and K. F. Barlizal: Depressed liver regeneration after partial hepatectomy of germ-free, athymic and lipopolysaccharide-resistant mice. Hepatology 11: 916-922 (1990).

Cressman, D. E., L. E. Greenbaum, R. A. Deangelis, R. A. Ciliberto, E. E. Furth, V. Poli and R. Taub: Liver failure and defective hepatocyte regeneration in interleukin-6-deficient mice. Science 274: 1379-1383 (1996).

Deimann, W. and H. D. FAHImI: The appearance of transition forms between monocytes and Kupffer cells in the liver of rats treated with glucan. A cytochemical and ultrastructural study. J. Exp. Med. 149: 883-897 (1979). 
- - Hepatic granulomas induced by glucan. An ultrastructural and peroxidasecytochemical study. Lab. Invest. 43: 172-181 (1980).

Delemarre, F. G., N. Kors, G. KraAl and N. Van RooIJEN: Repopulation of macrophages in popliteal lymph nodes of mice after liposome-mediated depletion. J. Leukoc. Biol. 47: 251-257 (1990).

Diehl, A. M. M., M. YiN, J. Fleckenstein, S. Q. YANG, H. Z. Lin, D. A. Brenner, J. Westwick, G. BAGBY and S. NELSON: Tumor necrosis factor $\alpha$ induces $\mathrm{c}$-jun during the regenerative response to liver injury. Amer. J. Physiol. 267: G552-G561 (1994).

Ebe, Y., G. Hasegawa, H. Takatsuka, H. Umezu, M. Mitsuyama, M. Arakawa, N. Mukaida and M. Naito: The role of Kupffer cells and regulation of neutrophil migration into the liver by macrophage inflammatory protein-2 in primary listeriosis in mice. Pathol. Int. 49: 519-532 (1999).

GaK, E., W. G. TAYloR, A. M. L. K. Chan and J. S. RUbiN: Processing of hepatocyte growth factor to the heterodimeric form is required for biological activity. BEBS Lett. 311: 17-21 (1992).

Gherard, E. and M. SToKer: Hepatocytes and scatter factor. Nature 346: 228 (1990).

HARDonk, M. J. and F. W. J. DiJkhuis: Influence of selective depletion of Kupffer cells by gadolinium chloride on silica-induced formation of granulomas. In: (ed. by) D.L. KNOOK and E. WISSE: Cells of the hepatic sinusoid, Vol. 4. Kupffer Cell Foundation, Leiden, 1993 (p. 101-104).

Hardonk, M. J., F. W. J. DiJkhuis and A. M. Jonker: Selective depletion of Kupffer cells by gadolinium chloride attenuates both galactosamine-induced and carbon tetrachloride toxicity in rats. In: (ed. by) E. WISSE, D. L. KNOOK and K. WAKE: Cells of the hepatic sinusoid, Vol. 5. Kupffer Cell Foundation, Leiden, 1995 (p. 29-32).

Higgins, G. M. and R. M. Anderson: Experimetal pathology of the liver. I. Restoration of the liver of the white rat following partial surgical removal. Arch. Pathol. 12: 186-202 (1931)

Isobe, S., S-T. Chen, P. K. Nakane and W. R. Brown: Studies on translocation of immunoglobulins across intestinal epithelium. I. Improvements to study the peroxidase-labeled antibody method for application to study of human intestinal mucosa. Acta Histochem. Cytochem. 10: 161-171 (1977).

KaGAN, E. and D. P. HartmanN: Elimination of macrophages with silica and asbestos. Methods Enzymol. 108: 325-353 (1984).

LAZAR, G.: The reticuloendothelial blocking effect of rare earth metals in rats. J. Reticuloendothel. Soc. 13: 231237 (1979).

Leenen, P. J. M., M. Melis, W. A. T. Slieker and W. VAN EWIJK: Murine macrophage precursor characterization. II. Monoclonal antibodies against macrophage precursor antigens. Eur. J. Immunol. 20: 27-34 (1990).

Leenen, P. J. M., M. F. T. R. De BruiJn, J. S. A. VoerMAN, P. A. CAMPBELL and W. VAN EwIJK: Markers of mouse macrophage development detected by mono- clonal antibodies. J. Immunol. Methods 176: 5-19 (1994).

MaheR, J. J.: Cell-specific expression of hepatocyte growth factor in liver. J. Clin. Invest. 91: 2244-2252 (1993).

Matsuda, Y, K. Matsumoto, A. Yamada, T. IChida, H. Asakura, Y. Komoriya, E. Nishiyama and T. NakaMURA: Preventive and therapeutic effects in rats of hepatocyte growth factor infusion on liver fibrosis/ cirrhosis. Hepatology 26: 81-89 (1997).

Matsumoto, K. and T. Nakamura: Hepatocyte growth factor as a tissue organizer for organogenesis and regeneration. Biochem. Biophys. Res. Commun. 239: 639-644 (1997).

Michalopoulos, G. K. and M. C. Defrances: Liver regeneration. Science 276: 60-66 (1997).

NaITo, M. and K. Takahashi: The role of Kupffer cells in glucan-induced granuloma formation in the mouse liver depleted of blood monocytes by administration of strontium-89. Lab. Invest. 50: 664-74 (1991).

Naito, M., H. NAGaI, S. KaWano, H. UmeZU, H. ZhU, H. Moriyama, T. Yamamoto, H. Takatsuka and Y. TAKEI: Liposome-encapsulated dichloromethylene diphosphonate induces macrophage apoptosis in vivo and in vitro. J. Leukoc. Biol. 60: 337-344 (1996).

Noguchi, S., Y. OHBA and T. OKA: Influence of epidermal. growth factor on liver regeneration after partial hepatectomy in mice. J. Endocrinol. 128: 425-431 (1991).

OGawa, K., A. Meduine and E. Farber: Sequential analysis of hepatic carcinogenesis: The comparative architecture of preneoplastic, malignant, prenatal, postnatal and regenerating liver. Brit. J. Cancer 40: 782-790 (1979).

RaI, R. M., S. Q. YanG, C. McClain, C. L. KaRP, S. KLEIN and A. M. DIEHL: Kupffer cell depletion by gadolinium chloride enhances liver regeneration after partial hepatectomy in rats. Amer. J. Physiol. 270: G909-G918 (1996).

Schmint, E., C. Bladt, S. GoEdeCKe, V. BRinkmanN, W. Sharpe, E. Gherardi and C. BIRChMeIER: Scatter factor/hepatocyte growth factor is essential for liver development. Nature 373: 699-702 (1995).

Schmirmacher, P., A. Geerts, W. Jung, H. P. Dienes and C. E. RUPGLER: Hepatocyte growth factor/ hempatopoietin $\mathrm{A}$ is expressed in fat-storing cells from rat liver but not myofibroblast-like cells derived from fat-storing cells. Hepatology 15: 5-11 (1992).

Shiota, G., T. WANG, T. Nakamura and E. Schmidt: Hepatocyte growth factor in transgenic mice: effects on hepatocyte growth, liver regeneration and gene expression. Hepatology 19: 962-972 (1994).

Skov Olsen, P., S. Boesby, P. KirkegaArd, K. Therkelsen, T. Almdal, S. Serer Poulsen and E. Nexo: Influence of epidermal growth factor on liver regeneration after partial hepatectomy in rats. Hepatology 8: 992-996 (1988).

Uehara, Y., O. Minowa, C. Mori, K. Shiota, J. Kuno, T. Noda and N. KitamuRa: Placental defect and embryonic lethality in mice lacking hepatocyte growth factor/scatter factor. Nature 373: 702-705 (1995). 
Van RoolJen N. and A. Sanders: Liposome mediated depletion of macrophages: mechanism of action, preparation of liposomes and applications. J. Immunol. Methods 174: 83-93 (1994).

Van RoolJen, N. and R. Van Nieuwnmegen: Elimination of phagocytic cells in the spleen after intravenous injection of liposome-encapsulated dichloromethylene diphosphonate. Cell Tiss. Res. 238: 355-358 (1984).

VAN Rooljen, N., N. Kors and G. KraAL: The liposomemediated macrophage. A suicide technique. J. Immunol. Methods 124: 1-6 (1989a).

- Macrophage subset repopulation in the spleen: Differential kinetics after liposomemediated elimination. J. Leukoc. Biol. 45: 97-104 (1989b).

VAN Rooljen, N. Kors, M. VAN DeR Ende and C. D. DiJkstra: Depletion and repopulation of macrophages in spleen and liver of rat after intravenous treatment with liposome-encapsulated dichloro-methylene diphosphonate. Cell Tiss. Res. 260: 215-222 (1990).

WidmanN, J-J. and D. H. FAHimi: Proliferation of mononuclear phagocytes (Kupffer cells) and endothelial cells in regenerating rat liver. Amer. J. Pathol. 80: 349-366 (1975).

YaMada, M., M. NaIto and K. TaKahashi: Kupffer cell proliferation and glucan-induced granuloma-formation in mice depleted of blood monocytes by strontium-89. J. Leukoc. Biol. 47: 195-205 (1990).
Yamada, Y., I. Kirillova, J. J. Peschon and N. Fausto: Initiation of liver growth by tumor necrosis factor: Deficient liver regeneration in mice lacking type I tumor necrosis factor receptor. Proc. Nat. Acad. Sci. USA 94: 1441-1446 (1997).

Yamamoto, T., M. Naito, H. Moriyama, H. UmezU, H. Matsuo, H. Kiwada and M. Arakawa: Repopulation of murine Kupffer cells after intravenous administration of liposome-encapsulated dichloromethylene diphosphonate. Amer. J. Pathol. 149: 1271-1286 (1996).

Prof. Makoto NAITO

Second Department of Pathology

Niigata University School of Medicine

Asahimachi-dori 1, Niigata

951-8510 Japan

Tel: +81-25-227-2102

Fax: +81-25-227-0761

E-mail: 2byori@med.niigata-u.ac.jp

内藤占

951-8510 新潟市旭町通 I

新潟大学医学部

第二病理学教室 